\title{
ANALYSIS OF BRIDGE GIRDER-2 WAY BEAM
}

\author{
SP Vijaykumar ${ }^{1}$, Kalpana Mohan ${ }^{2}$ \\ ${ }^{1}$ Assistant Professor, Department of Civil Engineering, Saveetha School of Engineering, Saveetha University, \\ Thandalam, Chennai-602105 \\ ${ }^{2}$ Assistant Professor, Department of Civil Engineering, Saveetha School of Engineering, Saveetha University, \\ Thandalam, Chennai-602105
}

\begin{abstract}
Bridge girder material, size, shape and selection are based on engineering and economic criteria. Steel concrete composite construction has gained wide acceptance as an alternative to pure steel and pure concrete construction, there is no need for formwork because the steel beam is able to sustain the self-weight of steel and concrete with few temporary props. In this paper, we present analysis and results of steel and steel reinforce bridge girders, based on STAAD Pro analysis and manual analysis. Various types of 2 way beams are taken and compared:

1. RCC $0.5 * 1$ WITH 2 WAY BEAM

2. RCC $0.4 * 0.8$ WITH 2 WAY BEAM

3. RCC I SHAPE WITH 2 WAY BEAM

4. STEEL I SHAPE WITH 2 WAY BEAM

The analysis was conducted between steel girders and reinforced concrete bridge girders. Based on the design calculations, effect of each girder with respect to shear, bending moment, dead load, live load, deflection and most importantly cost of each combination is analysed.
\end{abstract}

Keywords: Bridge Girder, Beam, STAAD Pro etc.

\section{INTRODUCTION}

\subsection{Bridge}

A Bridge is a structure built to span physical obstacles without closing the way underneath such as a body of water, valley, or road, for the purpose of providing passage over the obstacle. There are many different designs that each serve a particular purpose and apply to different situations. Designs of bridges vary depending on the function of the bridge, the nature of the terrain where the bridge is constructed and anchored, the material used to make it, and the funds available to build it.

Types of bridges:

- $\quad$ Girder bridges

- Arc bridges

- $\quad$ Truss bridges

- $\quad$ Suspended bridges

- $\quad$ Prestressed bridges

- $\quad$ Rigid Frame Bridges

\section{LITERATURE REVIEW}

Various journals and thesis were refereed and the design aspects were studied. Steel bridge based on Indian and European standards were done and the results were compared. They took Indian code IS 800:2007 and Europian code BS EN 1993. For constant span and depth, the total deflection of the girder increases as the grade of steel increases but the total weight decreases according to the Indian standards design. A similar behaviour is found for European standards i.e., as grade of steel increases, deflection increases and weight reduces.

A life cycle inventory analysis of steel and steel-reinforced concrete bridge girders, based on publicly available data was also conducted. Here for the initial construction of equivalent designs for a particular location, a steelreinforced concrete bridge generally has lower environmental effects than a steel bridge Reuse and recycling of steel has used for construction of bridge for steel super structure reuse material upto $17 \%$ and recycle for $21 \%$.

\section{METHODOLOGY: GIRDER BRIDGE}

A girder bridge, in general, is a bridge that uses girders as the means of supporting the deck. A bridge consists of three parts: the foundation (abutments and piers), the superstructure (girder, truss, or arch), and the deck. A girder bridge is very likely the most commonly built and utilized bridge in the world. Its basic design, in the most simplified form, can be compared to a log ranging from one side to the other across a river or creek. In modern girder steel bridges, the two most common shapes are plate girders and boxgirders. The term "girder" is often used interchangeably with "beam" in reference to bridge design. 


\subsection{Different Types of Girder in Bridge}

\section{According to Shape}

Box Shape, I Shape, T Shape, C Shape

\section{According to Length of Bridge}

Culvert bridge(less than $6 \mathrm{~m}$ ), Minor bridge(less than $6 \mathrm{~m}$ $60 \mathrm{~m})$, Major bridge(more than $60 \mathrm{~m}$ ), Long span bridge(more than $120 \mathrm{~m}$ )

\subsection{Input of Bridge}

- $\quad$ Length of bridge $=15 \mathrm{~m}$

- Width of carriage bridge $=8.550 \mathrm{~m}$

- Width of footpath $=1.5 \mathrm{~m}$

- Total width $=11.550 \mathrm{~m}$

- Thickness of deck slab $=0.225 \mathrm{~m}$

- Thickness of wearing coat $=0.075 \mathrm{~m}$

- Number of girders $=4$

- $\quad$ Spacing of main girder $=2.850 \mathrm{~m}$

\subsection{Unit Weights \& Loads}

- reinforced cement concrete $=40 \mathrm{kn} / \mathrm{m} 3$

- $\quad$ wearing coat $=22 \mathrm{kn} / \mathrm{m} 3$

- $\quad$ structural steel $=78.5 \mathrm{kn} / \mathrm{m} 3$

- $\quad$ steel used fe 415
- $\quad$ irc class aa\& class a wheeled loads calculated as per irc :6-2000

- if span $7.5 \mathrm{~m}$ to $30 \mathrm{~m}$

- where $\mathrm{p}^{\prime}=400$ or $500 \mathrm{~kg} / \mathrm{m} 2$ from sub class 209.1 irc6

- formula cal. for 11 for footpath $=4.5 \mathrm{kn} / \mathrm{m}$

$$
P=P^{1}-\left(\frac{40 L-300}{9}\right)
$$

\section{STEP 1: Analysis of Bridges using Staad Pro}

\subsubsection{Rectangular Girder Size 0.5 x 1 m with Beam (2way)}

Step for doing rectangular girder size $0.5 \times 1 \mathrm{~m}$ with 2 way beam. Here in ' $y$ ' axis beams are known as girder and giving property as width $0.5 \mathrm{~m}$ and depth as $1 \mathrm{~m}$. Support is fixed. Our bridge width is $11.55 \mathrm{~m}$ and carriage width is $8.55 \mathrm{~m}$. No. of lanes for design purposes is two lanes. Load combination is one lane of class $70 \mathrm{R}$ or two lanes of Class A. Moving load at tires are 2.7,2.7,11.4,11.4,6.8,6.8,6.8,6.8 tons at distance of 1.1,3.2,1.3,4.3,3,3,3 respectively. Width of vehicle is $1.8 \mathrm{~m}$. These loads are places at vehicle definition in STAAD Pro. Make the load generation as 250 combinations.

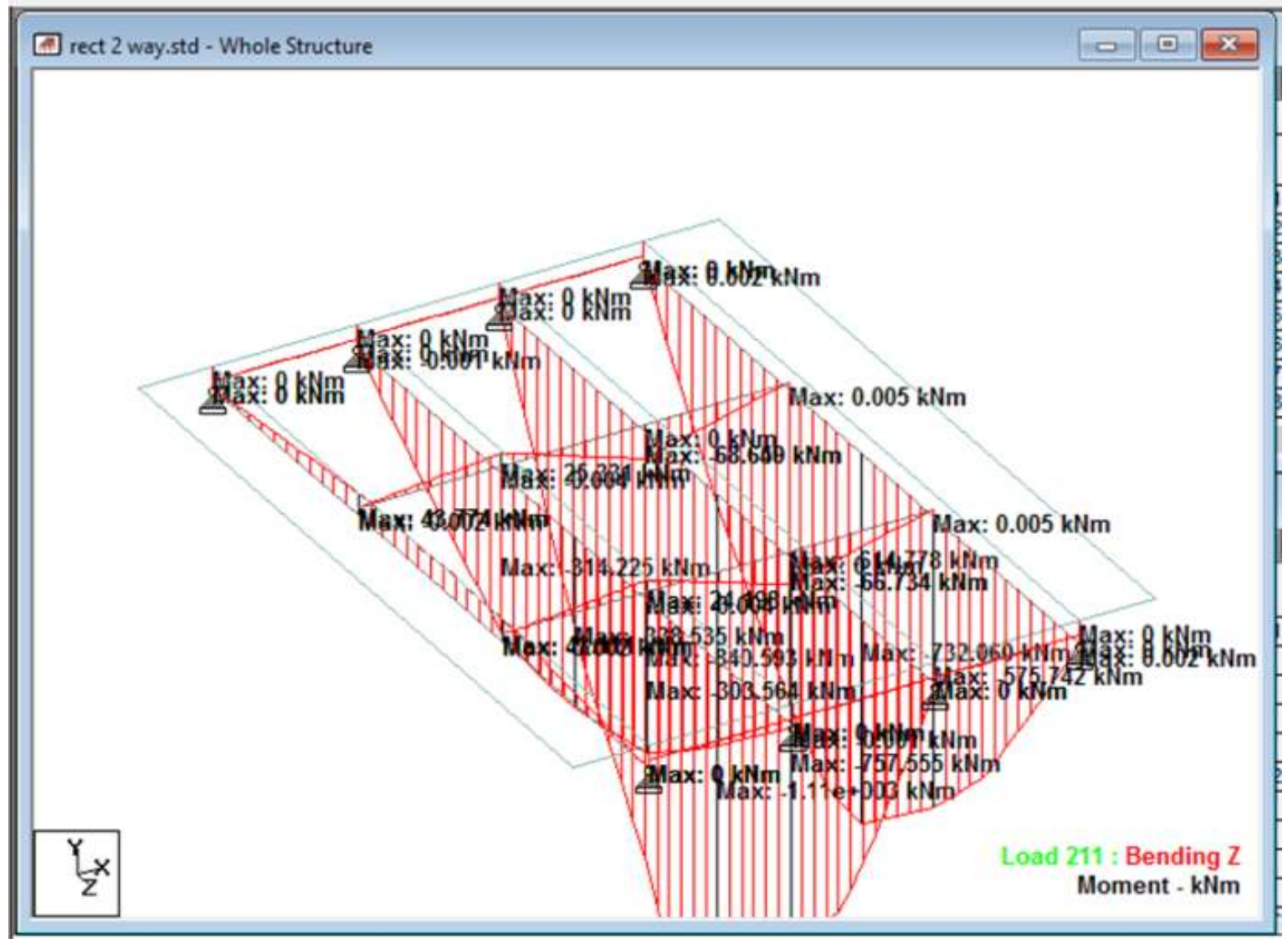

Fig 3.1 Bending of Rectangular girder size $0.5 \times 1 \mathrm{~m}$ with 2 way beam 


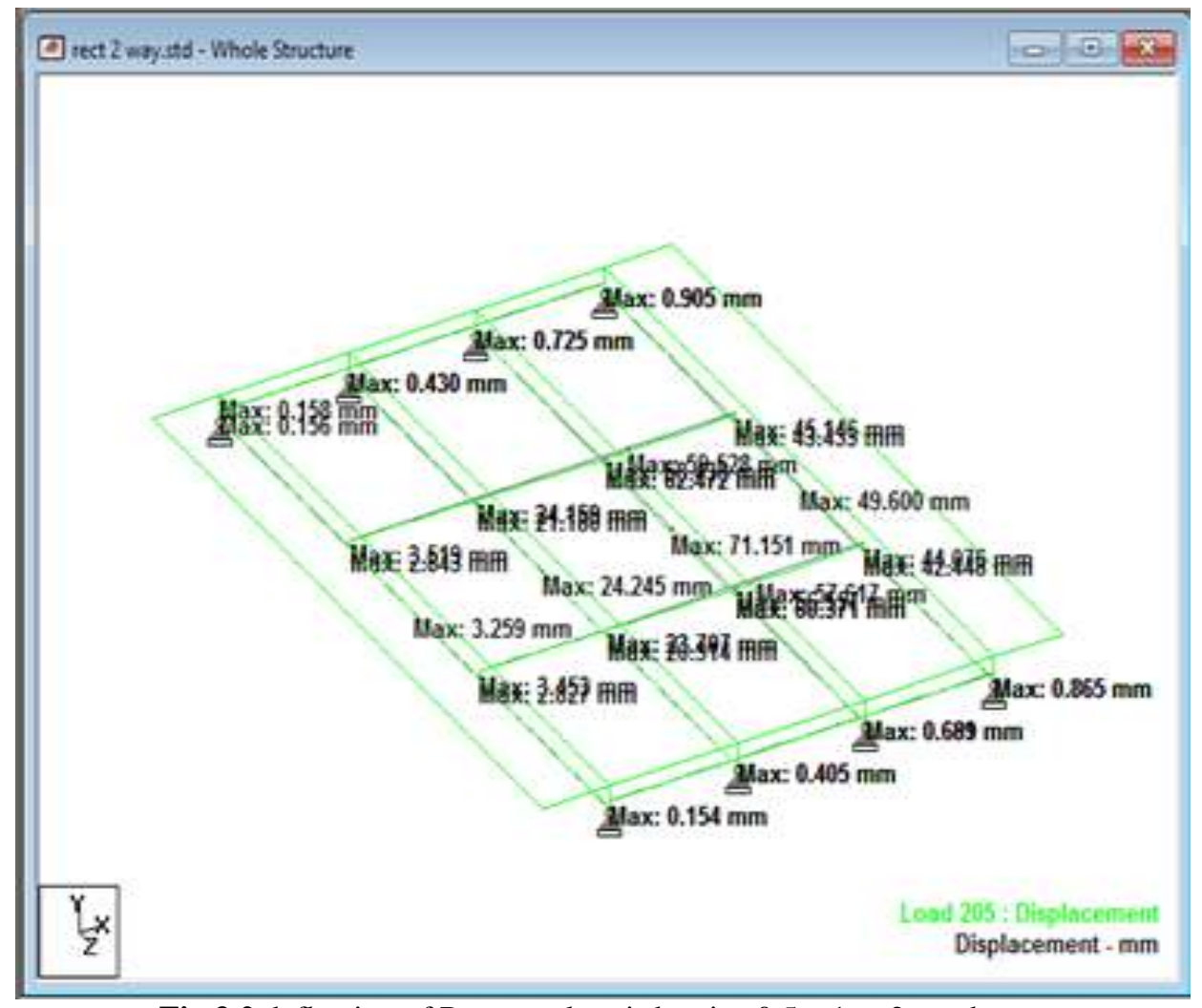

Fig 3.2 deflection of Rectangular girder size 0.5 x $1 \mathrm{~m} 2$ way beam

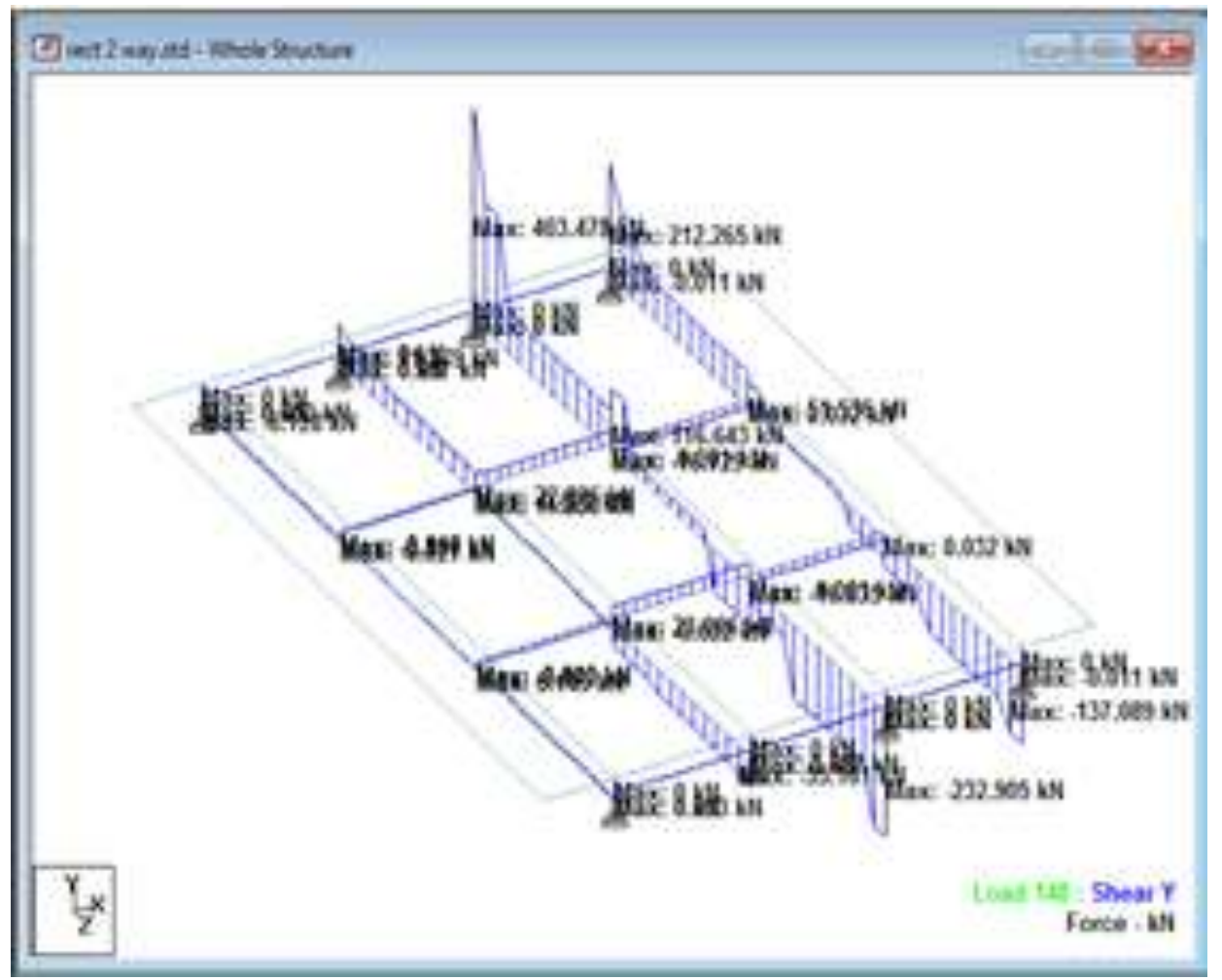

Fig 3.3 shear of Rectangular girder size 0.5 x $1 \mathrm{~m}$ with beam ( 2 way):

\subsubsection{Rectangular Girder Size 0.4 x 0.8 m with 2}

\section{Way Beam:}

It is similar to Rectangular girder size of $0.5 \mathrm{x} 1 \mathrm{~m}$ with 2 way beam. Here only girder size in y axis is changed. Width of the girder is 0.4 meter and depth of the girder is 0.8 meters. Supports and vehicle load combination is similar. Here also 250 load combinations is generated. Values of Deflection, bending moment and Shear force is changed compared with the rect $0.5 \times 1 \mathrm{~m}$. 


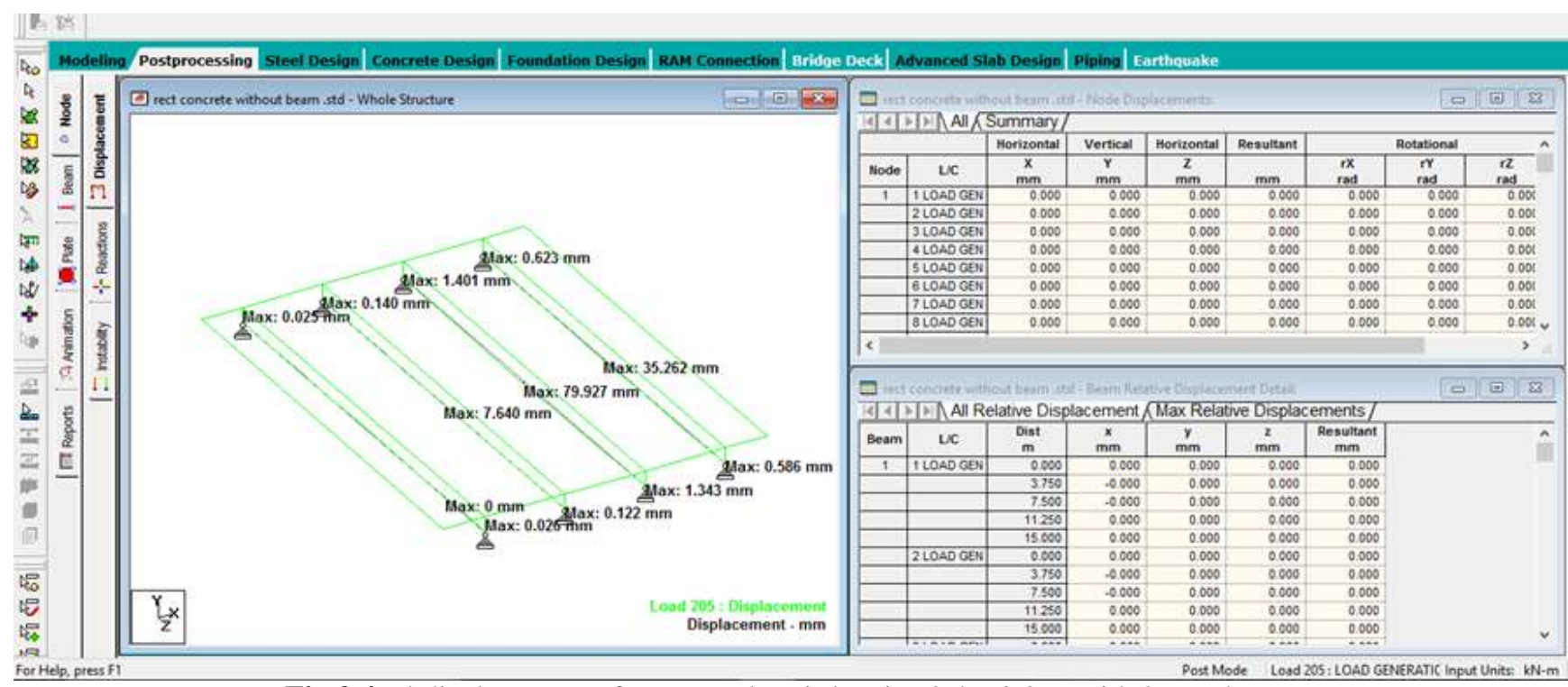

Fig 3.4. 4 displacement of Rectangular girder size $0.4 \times 0.8 \mathrm{~m}$ with 2 way beam

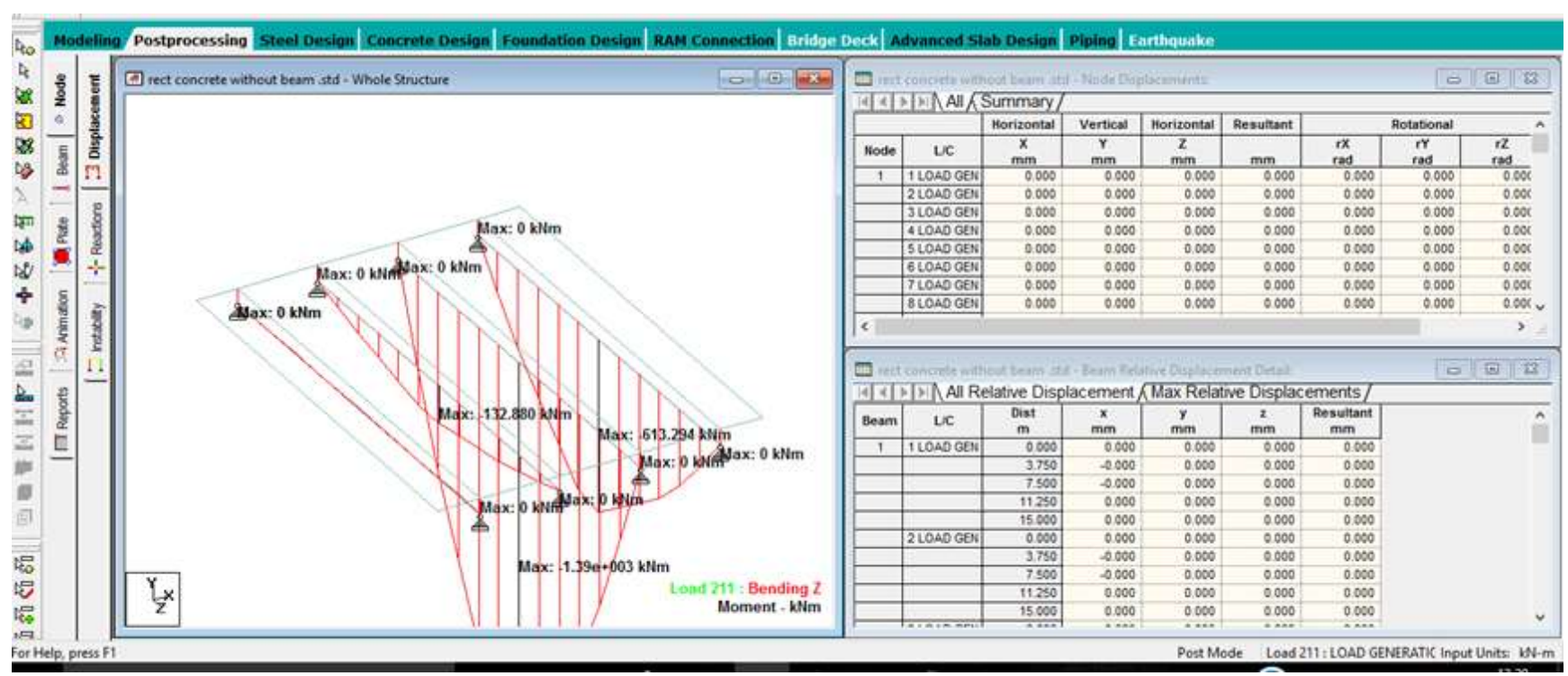

Fig 3.5: bending of Rectangular girder size 0.4 x $0.8 \mathrm{~m}$ with 2 way beam

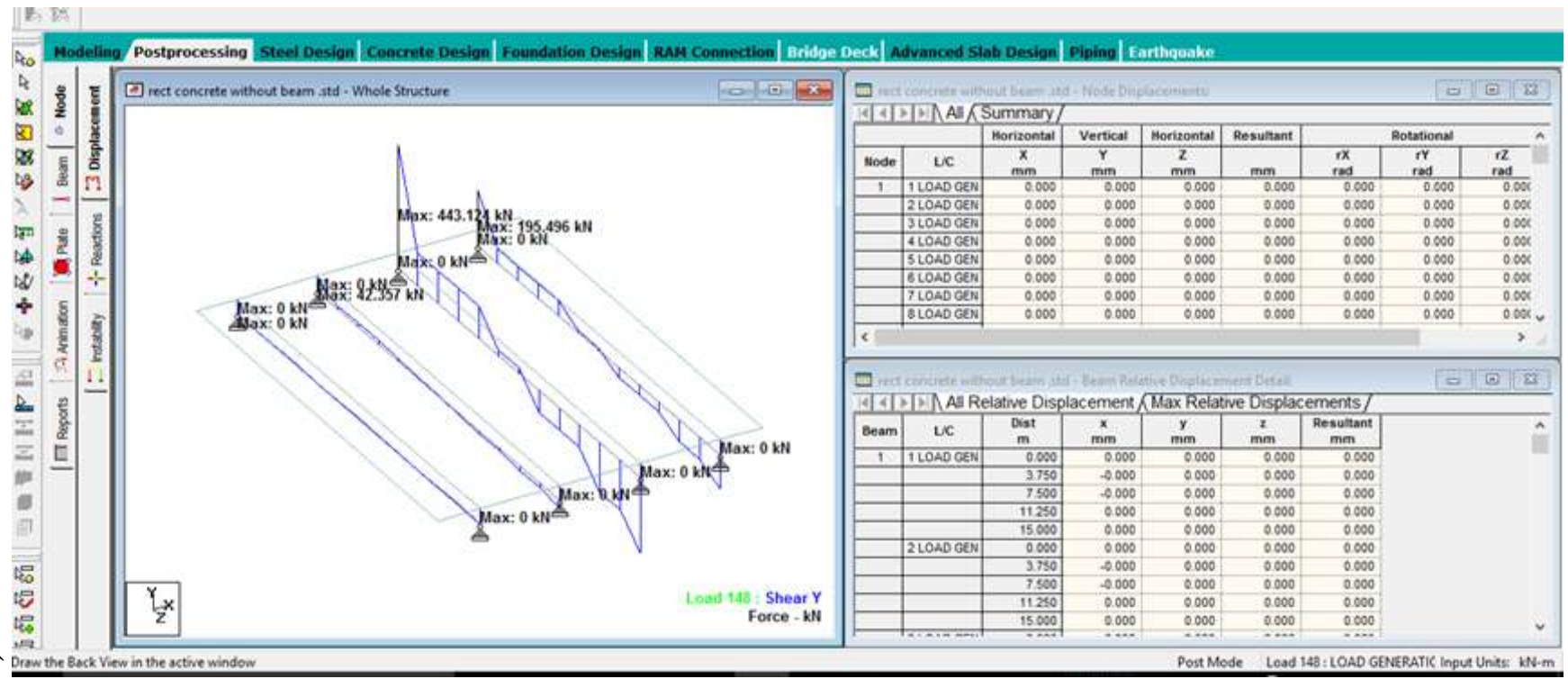


Fig 3.6: Shear of Rectangular girder size $0.4 \times 0.8 \mathrm{~m}$ with 2 way beam

\subsubsection{Shaped Rec Girder with Beam (2way)}

It is similar to I shaped Rcc girder without beam. Beams are placed at starting point of bridge and ending point of bridge that is zero meter and 15 meter. Cross Beam sized in I
Shaped RCC girder size of $0.3 * 0.15 \mathrm{~m}$. Similar load are given in bridge as given before for without beam. Take Maxmium Deflection, Bending Moment, Shear force at 205,211, 148 combinations respectively.

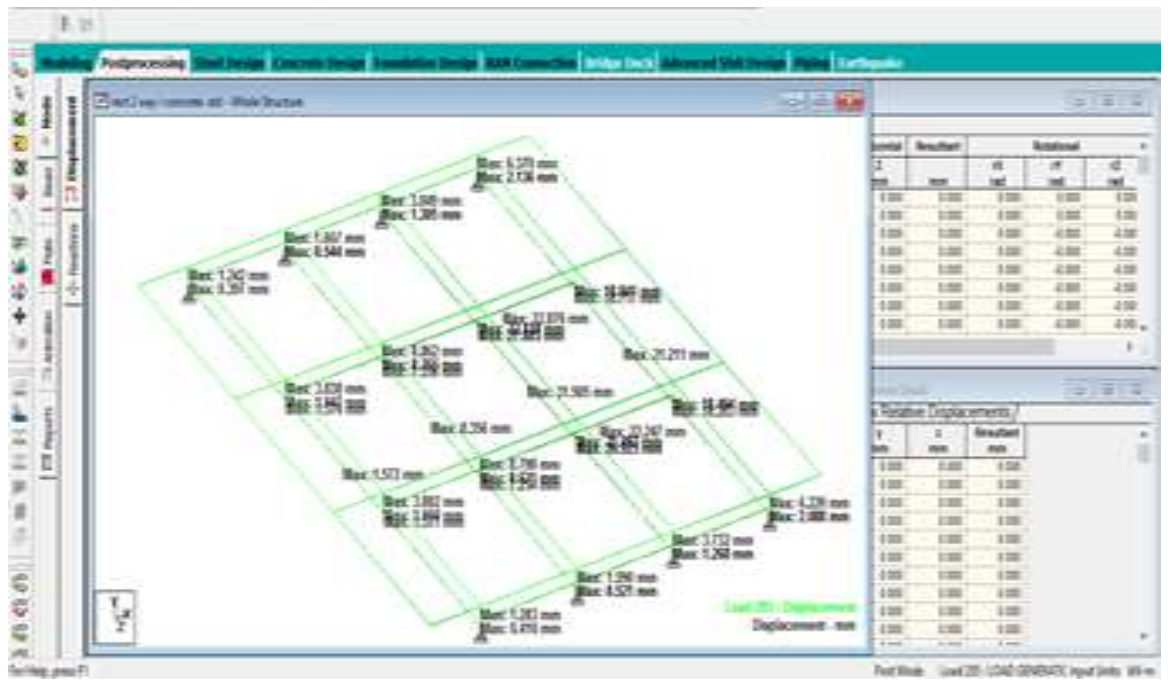

Fig 3.7: Displacement I shaped rcc girder with beam (2way)

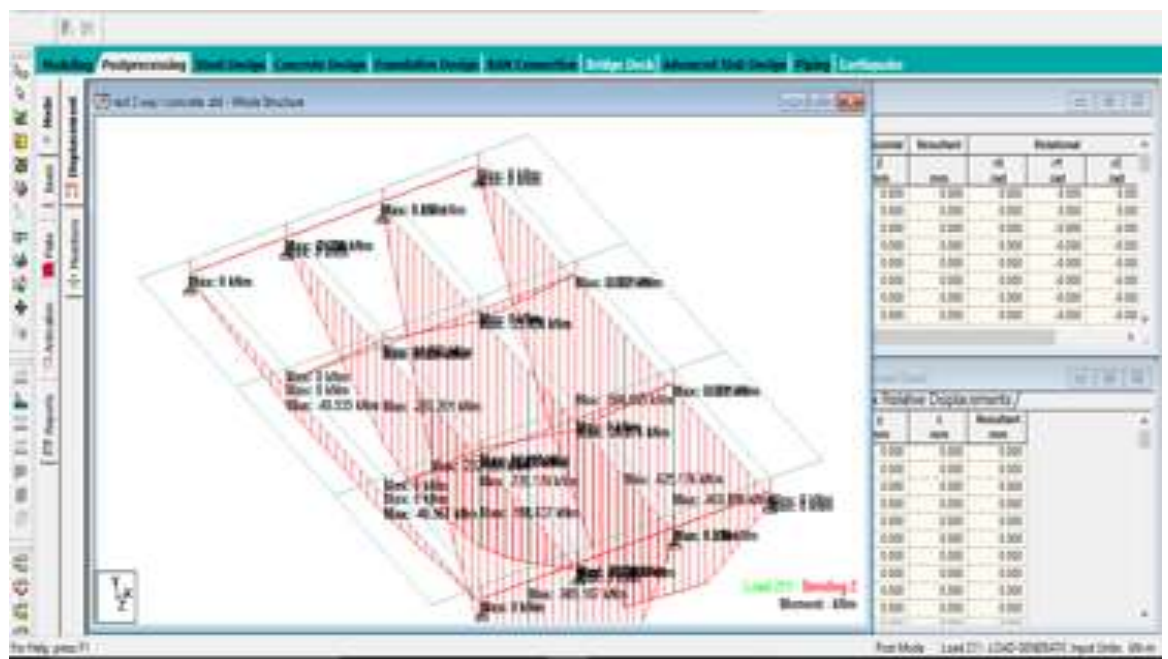

Fig 3.8: Bending I shaped rcc girder with beam (2way)

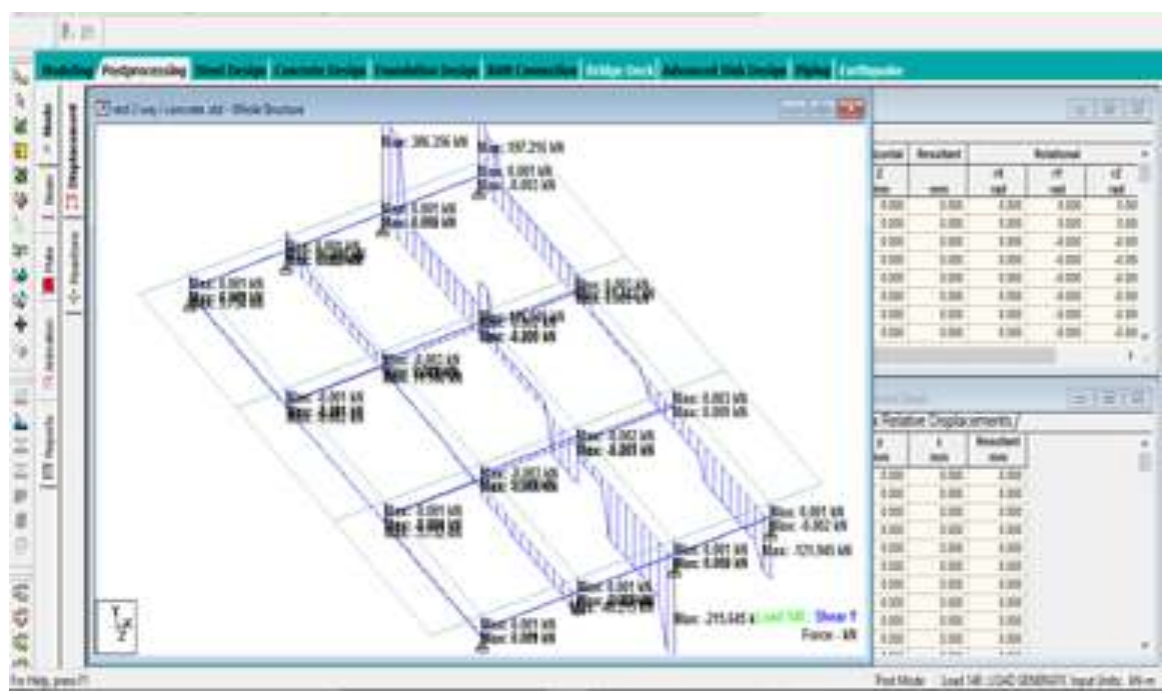


Fig 3.9: shear I shaped rcc girder with beam ( 2 way)

\subsubsection{Shaped Steel Girder with Beam (2way)}

It is similar to I shaped rec girder with beam (2 way).

\section{RESULTS AND DISCUSSIONS}

In this results and discussion the values for Deflection, Bending moment and Shear force is taken from the staad pro. Maximum Deflection occur at combination number :205. Maximum Bending moment occur at combination

\subsection{Estimation}

number :211. Maximum Shear force occur at combination number :148. From the above values without beam and beam (one way) have approximately values. All these values are in dynamic conditions. Because in 15 meter span we are giving cross beam at $5 \mathrm{~m}$ and $10 \mathrm{~m}$ distance. When moving load is at from 0 to $5 \mathrm{~m}$ and 10 to $15 \mathrm{~m}$ then deflection, bending moment, shear at 5 to $10 \mathrm{~m}$ it become lesser than without beam and beam

Table 4.1 Values Form Staad pro Rectangular 0.5 X 1m sized girder

\begin{tabular}{|l|l|l|l|l|l|l|l|l|l|l|l|l|l|}
\hline \multicolumn{4}{|c|}{ DEFLECTION } & \multicolumn{4}{l|}{ BENDING MOMENT } & \multicolumn{3}{l|}{ SHEAR } \\
\hline $\begin{array}{l}\text { DESCRIP } \\
\text { TION }\end{array}$ & $\begin{array}{l}\text { COMB } \\
\text { INATION }\end{array}$ & G1 & G2 & G3 & G4 & G1 & G2 & G3 & G4 & G1 & G2 & G3 & G4 \\
\hline 2 WAY & 205 & 0.846 & 2.551 & 29.041 & 12.35 & 0.1 & 120.082 & 1230 & 575.434 & 0 & -14.881 & $\begin{array}{l}254.714 \\
-280.695\end{array}$ & $\begin{array}{l}135.027 \\
-131.141\end{array}$ \\
\hline 2 WAY & 211 & 0.35 & 2.481 & 28.791 & 12.199 & 0.1 & 120.508 & 1230 & 585.434 & 0 & -24.937 & $\begin{array}{l}231.265 \\
-304.926\end{array}$ & $\begin{array}{l}128.274 \\
-130.581\end{array}$ \\
\hline 2WAY & 148 & 0.590 & 1.558 & 20.134 & 9.315 & 22.052 & 60.411 & 783.006 & 357.830 & 0 & $\begin{array}{l}-39.685 \\
+509.949\end{array}$ & $\begin{array}{l}-250.644 \\
+421.182\end{array}$ & $\begin{array}{l}-129.074 \\
204.272\end{array}$ \\
\hline
\end{tabular}

Table 4.2 Values Form Staad pro Rectangular 0.4 X $0.8 \mathrm{~m}$ sized girder

\begin{tabular}{|l|l|l|l|l|l|l|l|l|l|l|l|l|l|}
\hline $\begin{array}{l}\text { DESCRI } \\
\text { PTION }\end{array}$ & $\begin{array}{l}\text { COM } \\
\text { BIN } \\
\text { ATION }\end{array}$ & \multicolumn{3}{|l|}{ DEFLECTION } & \multicolumn{1}{l|}{ BENDING MOMENT } & \multicolumn{2}{l|}{ SHEAR } \\
\hline $\begin{array}{l}\text { C0N } \\
\text { CRETE } \\
.8 \times 0.4\end{array}$ & & G1 & G2 & G3 & G4 & G1 & G2 & G3 & G4 & G1 & G2 & G3 & G4 \\
\hline 2 WAY & 205 & 2.463 & 4.843 & 64.867 & 32.504 & 38.916 & 113.9 & 1140 & 510.774 & 0 & $\begin{array}{l}+15.545- \\
13.777\end{array}$ & $\begin{array}{l}236.612- \\
262.992\end{array}$ & $\begin{array}{l}+147.434- \\
128.388\end{array}$ \\
\hline 2 WAY & 211 & 2.433 & 4.247 & 64.346 & 32.101 & 37.666 & 110.915 & 1150 & 516.533 & - & $\begin{array}{l}+10.889- \\
7.52 \\
17.543\end{array}$ & $\begin{array}{l}213.416- \\
287.354\end{array}$ & $\begin{array}{l}136.542- \\
138.762\end{array}$ \\
\hline 2 WAY & 148 & 1.718 & 3.549 & 44.952 & 19.520 & 26.460 & 65.198 & 720.514 & 266.895 & 5.27 & $\begin{array}{l}37.489- \\
31.252\end{array}$ & $\begin{array}{l}408.707- \\
238.154\end{array}$ & $\begin{array}{l}180.076- \\
134.892\end{array}$ \\
\hline
\end{tabular}

Table 4.3 Values Form Staad pro I shaped rcc girder

\begin{tabular}{|c|c|c|c|c|c|c|c|c|c|c|c|c|c|}
\hline $\begin{array}{l}\text { DES } \\
\text { CRI } \\
\text { PTION }\end{array}$ & $\begin{array}{l}\text { COM } \\
\text { BIN } \\
\text { ATION }\end{array}$ & \multicolumn{4}{|c|}{ DEFLECTION } & \multicolumn{4}{|c|}{ BENDING MOMENT } & \multicolumn{4}{|c|}{ SHEAR } \\
\hline $\begin{array}{l}\text { I } \\
\text { SHAPE }\end{array}$ & & G1 & G2 & G3 & G4 & G1 & G2 & G3 & G4 & G1 & G2 & G3 & G4 \\
\hline 2 WAY & 205 & 0.572 & 8.356 & 31.505 & 21.211 & 41.032 & 123.490 & 980.57 & 601.617 & 8.193 & $-19.90+47.62$ & $\begin{array}{l}-231.697 \\
+204.522 \\
\end{array}$ & $\begin{array}{l}-130.25 \\
+128.56 \\
\end{array}$ \\
\hline 2 WAY & 211 & 0 & 8.352 & 31.500 & 21.10 & 40.565 & 123.559 & 989.11 & 605.176 & 8.107 & $\overline{52.010+45.061}$ & $256.075+181.915$ & $130.668+48.085$ \\
\hline $2 \mathrm{WAY}$ & 148 & 1.103 & 5.860 & 22.022 & 14.852 & 28.770 & 65.076 & 608.231 & 352.305 & 5.754 & $36.489-40.215$ & $386.356-215.645$ & $\begin{array}{l}193.216 \\
-121.945\end{array}$ \\
\hline
\end{tabular}

Table 4.4 Values Form Staad pro I shaped steel girder

\begin{tabular}{|c|c|c|c|c|c|c|c|c|c|c|c|c|c|}
\hline $\begin{array}{l}\text { DES } \\
\text { CRI }\end{array}$ & $\begin{array}{l}\text { COM } \\
\text { BIN }\end{array}$ & \multicolumn{4}{|c|}{ DEFLECTION } & \multicolumn{4}{|c|}{ BENDING MOMENT } & \multicolumn{4}{|c|}{ SHEAR } \\
\hline $\begin{array}{l}\text { I SHAPE } \\
\text { STEEL }\end{array}$ & & G1 & G2 & G3 & G4 & G1 & G2 & G3 & G4 & G1 & G2 & G3 & G4 \\
\hline 2 WAY & 205 & 0.107 & 0.744 & 9.401 & 4.143 & 13.360 & 122.962 & 1330 & 585.304 & 0 & $27.489-39.823$ & $274.335-300.02$ & $\begin{array}{l}131.049 \\
-142.276\end{array}$ \\
\hline 2 WAY & 211 & 0.106 & 0.730 & 9.319 & 3.902 & 0 & 123.811 & 1340 & 539.941 & 0 & $25.852-42.011$ & $250.577-324.08$ & $120.420-132.789$ \\
\hline 2 WAY & 148 & 0.075 & 0.534 & 6.521 & 2.553 & 0 & 80.436 & 850.953 & 310.192 & 0 & $\begin{array}{l}45.369 \\
-33.083\end{array}$ & $434.754-264.262$ & $190.751-123.543$ \\
\hline
\end{tabular}

\section{Estimation in 15 meter span we are giving cross beam at $5 \mathrm{~m}$ and $10 \mathrm{~m}$ distance.}

- When moving load is at from 0 to $5 \mathrm{~m}$ and 10 to $15 \mathrm{~m}$ then deflection, bending moment, shear at 5 to $10 \mathrm{~m}$ it become lesser than without beam and beam 


\begin{tabular}{|l|l|l|}
\hline NO. & NAME OF BRIDGE & AMOUNT \\
\hline 3. & RCC $0.5 * 1$ TWO WAY BEAMS & $1,79,481.95$ \\
\hline 6. & RCC $0.4 * 0.8$ TWO WAY BEAMS & $1,71,161.95$ \\
\hline 9. & RCC I SHAPE TWO WAYBEAMS & $1,96,724.05$ \\
\hline 12. & STEEL I SHAPE TWO WAY BEAMS & $1,70,206.3$ \\
\hline
\end{tabular}

\section{CONCLUSION}

Different arrangement of deck slab with girder was taken like, beams at edges taken as one way slab and beams in between making deck slab two way.. In two way deck slab shear force results has positive and negative values. With normal IRC loading bridge with girder spacing of $2.850 \mathrm{~m}$ with span of $50 \mathrm{~m}$ the working load in bending moment the order of 1600-1800 kN.m and shear force values comes in the order of $400-450 \mathrm{kN}$. Where as per the staad pro terms $1390 \& 440$ it appears to be reasonable. Comparing rcc and steel girder bridge I shaped steel is more economical

\section{REFERENCES}

[1] Construction of Maltekadi Railway Over Bridge On Mini Bypass Road Link Road MSH2 Nanded City Navi Mumbai. Design of PSC I Girder. (SPAN $14.132 \mathrm{M}$ c/c Piers).

[2] Comparison of Design Standards for Steel Railway Bridges(Midhun B Sankar,Priya A Jacob)

[3] STEEL VERSUS STEEL-REINFORCED CONCRETE BRIDGES : By Arpad Horvath and Chris Hendrickson

[4] Are Reinforced Concrete Girder Bridges More Economical Than Structural Steel Girder Bridges(Trevor Haas:dept civil)

[5] Analysis of Plate Girder Bridge for Class-AA Loadings. Authors Mr.Shivraj D. Kopare ,Prof. K. S. Upase

[6] Behavior of Concrete Bridge Decks Reinforced with High-Performance Steel(by Hatem M. Seliem, Gregory Lucier, Sami H. Rizkalla; and Paul Zia)

[7] T.R Jagadeesh, M.A.JAYARAM, Design of bridge structure 2009

[8] AmarjitAggarwal and A.K. Upadhyay , civil estimating, costing and valuation, 7 th edition, 2008

[9] S.C.Rangwala, K.S.Rangwala, civil estimating, costing and valuation , 17th edition, 2015

[10] Analysis \& Design of 46m composite span for ROBs at Chainage $\mathrm{km}: 8+981 \& \mathrm{~km} \mathrm{3+477}$. Simhapuri Expressway Limited KMC - BSCPL (Consortium), Banjara Hills, Hyderabad 